\title{
Feed-in-Tariff To Encourage Private, Local Government, Social Enterprise, and Residential to Contribute on Achieving 870 MW Photovoltaic Generation by 2025
}

\author{
I.N.S. Kumara, W.G. Ariastina, I.A.D. Giriantari, W. Sukerayasa
}

\section{INTRODUCTION}

Feed-in-tariff (FIT) is a policy mechanism introduced by Government to encourage deployment of renewable energy technologies. Historically, FIT is associated with a German model in which Government mandates utilities to set up long-term contracts, normally 20 years, with power producers at specified energy rates which typically above the retail price of electricity. Countries in Europe and America have long adopted the use of FIT and countries in Asia Pacific such as Australia, China, India, Japan, Korea, Malaysia, Mongolia, Myanmar, New Zealand, Philipines, Singapore, Thailand, and Vietnam are at different stage of FIT implementation.

Renewable energy industry has a big challenge to make the cost of clean energy competitive with fossil-based energy, which do not internalize the cost of environmental impacts and are often subsidized. Without political measures to increase consumer demand and facilitate access to the market, then renewable technology manufacturers cannot bring down the price due to limited unit production and create technological innovation.

The FIT has proven as one of the most effective policy instruments in overcoming the cost barrier to introduce renewable technology and to make it economically attractive. The key elements that FIT provide as guarantees are access to the gridand a set price per kilo Watt hour (kWh) that will cover the cost of electricity production. These have turned several Eropean countries into world leader in the renewable energy sector such as Denmark on the case of wind energy and Germany on solar generation. 
Policy Recommendations

- MEMR needs to identify all of its own NRE regulations and any external regulations, by other ministries or state agencies, and harmonizing all regulations to create certainty among NRE stakeholders, particularly NRE developer.

- In view of huge task of Government to develop more PV plant ot meet the 2025 target, the Government would still need to build more power plants together with the participation of stakeholders, then clear guidelines should be issued to prepare future grant (power plant) recipient in conducting negotiation with the utility to reach agreement of the FIT.

- Guidelines on how FIT shall be given to non-power developer such as NGOs, social enterprise, CSR-based plants, international aid funded power plant, and the like should be issued so plant's operator (grant receipient) can prepare the required steps to reach agreement with the utility prior completion of the projects.

- Guidelines should be issued for the utility, PLN Distribusi of area in which the plant is located, to prevent unnecessary long time to reach agreement which will impact on plant's reliability.

- With regard to current government funded projects, MEMR should produce guidelines both for grant recipient and the utility so that agreement between the two parties over FTI rate can be achieved. Perusda that received the power plant as grant will also invest in the future to ensure the plant will continue working according the design and therefore should also receive fair FIT rate although they do not contribute on the intial investment. If this cannot be achieved that future power plants will likely to experience similar problems.

Fig. 1 shows how photovoltaic capacity in Germany increased exponentially after the introduction of FIT in 2000.

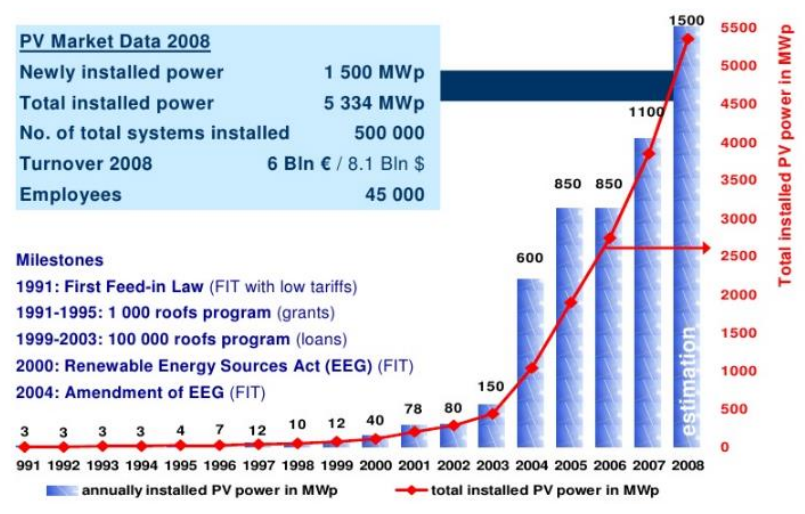

Fig.1German PV power development

Fig. 2 shows similar situation in the United Kingdom in which photovoltaic capacity increased nearly exponentially since the introduction of FIT in 2010.

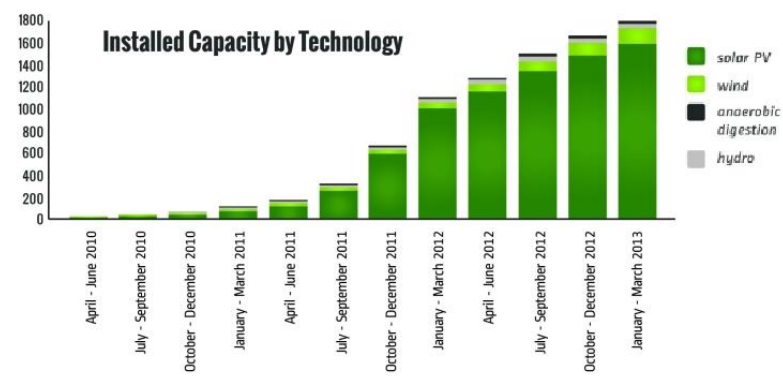

Fig.2 FIT impacts on renewable capacity in UK

Some benefits of well-designedFIT regulation include reduction of $\mathrm{CO}_{2} \mathrm{emissions}$, creation of jobs, more secure domestic energy supply, increased drive for technology innovation, and creation of fair market condition for renewable technologies.

\section{RENEWABLE GENERATION CHALLENGES INDONESIA}

Renewable power generation of Indonesia is still very low compared with resource potential and target set by 
Government to achieve 23\%renewable contribution by 2025. Three key elements that hampered development of renewable energy sector according to MEMR are (1) technology, (2) funding, and 3) regulation. Although, technology and funding are key challenges, but many of Indonesian strategic industry did not start with technology nor funding as these two factors were not sufficiently available. This perhaps a typical environment for developing countries. Regulation is the key element that determine how foreign technologies can be successfully imported and then developed domestically to support national development. Without a clear conducive policy and regulations, it is unlikely that the two factors, i.e. technology and funding would come along on the scale set in the national targets. In the case of renewable technology, as described in the introduction section, it is heavily relied upon Government policy. The FIT set by German and United Kingdom governments led to huge increased inrenewable generation capacity over relatively short period of time.

\section{FEED TARIFF FOR PV IN INDONESIA}

Feed-in-tariff in Indonesia was initiated by the release of MEMR Decree \#1122/2002concerning small-scale distributed generation (DG) or Pembangkit Skala Kecil Tersebar. This FIT applies to all forms of DG without any specific consideration over technologies used for power generation. However, this regulationspecifically limit the type of DG developer to small enterprise only with maximum power generation capacity of 1 megawatt (MW). The FIT rate was specified as $80 \%$ of the production cost if power is injected through medium voltage network and $60 \%$ of production cost if connected via low voltage network. This FIT had little impacts over generation capacity due to terms and conditions set in the regulation.

In 2013, MEMR issued another FIT specifically for photovoltaic distributed generation, MEMR Decree $\# 17 / 2013$. This regulation set the rate of 25 cent/kWh for power plant built using less than $40 \%$ domestically produced components and 30 cent/kWh for plant that uses more than $60 \%$ domestic products. This new FIT regulation is seen by many stakeholder could play important role in shaping the development of photovoltaic generation in Indonesia.

\section{GRID-CONNECTED PV in INDONESIA}

Some of major grid-connected photovoltaic projects in Indonesia includes 30 kW PLTS Nusa Penida, 1 MW PLTS Bangli, 1 MW PLTS Karangasem, 1 MW PLTS Sumbawa, and PLTS 5 MW Kupang.PLTS Nusa Penida was installed in the island of Nusa Penida by PLN in 2007 as part of the Indonesian preparation in hosting United Nation Conference on Climate Change (UNFCC) 2007 in Nusa Dua Bali. As the plant was built by the utility itself then there was no issues with regards to energy sale.

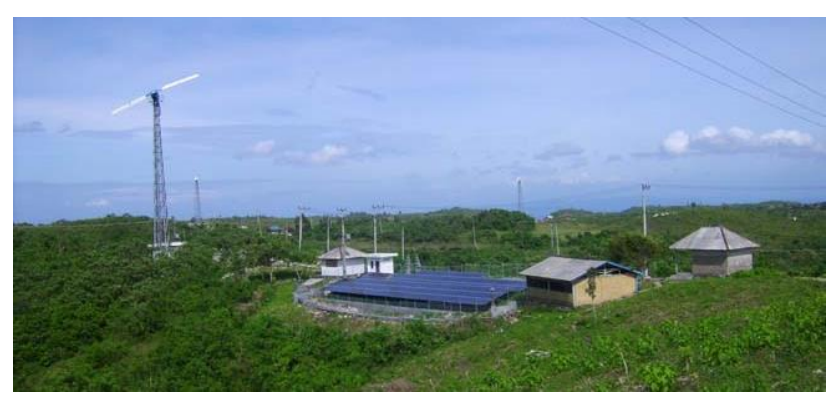

Fig. 3 PLTS 30 kW Nusa Penida

In 2013, MEMR officially turned the first large-scale gridconnected photovoltaic plants of the country. In fact, MEMR turned on three units of $1 \mathrm{MW}$ plants; $1 \times 1 \mathrm{MWp}$ PLTS Kayubihi in District of Bangli, 1 x 1 MWp PLTS Kubu in District of Karangasem, and 1 x 1 MWp PLTS Labangka in Sumbawa island of East Nusa Tenggara.

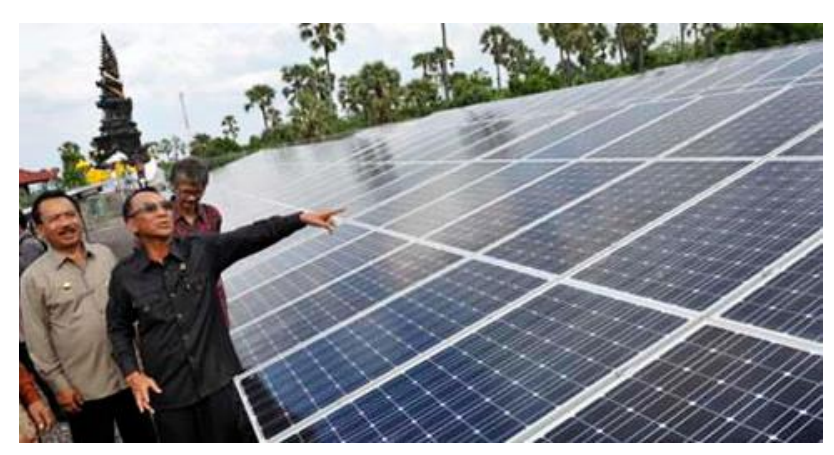

Fig. 4Former Minister of MEMR (M), Head of District Karangasem (L), and Dirjen EBTKE (R) at PLTS $1 \mathrm{MW}$ Karangasem 
These three power plants were symbolically handed over to the local district governments on February 27, 2013,PLTS Kubu is handed over to the Head District of Karangasem, PLTS Kayubihi was handed to the Head District of Bangli, and PLTS Labangka to the Head District of Labangka.

District governments of Karangasem and Bangli acted swiftly to respond the decision of MEMR to grant the power plant into their property assets and hence their management which includes the sale of energy to the utility. This obviously seen as source of revenue by the local government as well as other intangible outcomes generated by having renewable energy generation within their area.

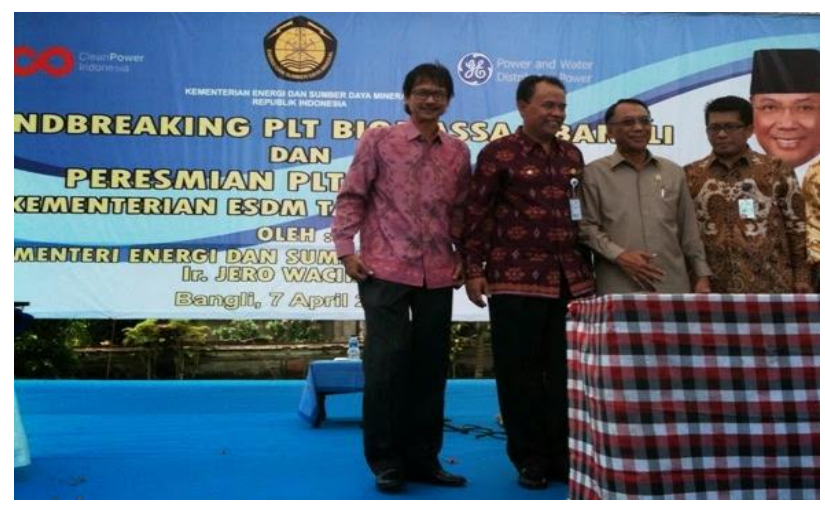

Fig. 5Drjen EBTKE, Head of District Bangli, Former Minster MEMR, President Director PLN (from left to right) at the launching of PLTS Kayubihi

Department of Electrical and Computer Engineering Udayana University was involved during the preparation of the handover. District of Bangli developed government enterprise called Perusahaan Daerah(Perusda) PLTS Kayubihi. Similar approach was also taken by District of Karangasem by establishing Perusda PLTS Karangasem. The two district governments were initially very keen to be involved in this pilot projects mainly due to the economic benefits the power plant could contribute toward their locally-generated revenue and also the fact that they have contributed in the projects by providing the land to build the power plants. There was little information with regard to PLTS Labangka Sumbawa but media reports suggested that the plant experience major drawbacks due to technical designs.
PLTS 5 MW Kupang was developed by PT. LEN Indonesia in 2015. It is located in Sub-district Oelpuah, City of Kupang, East Nusa Tenggara province. This project is the first fully private funded grid-connected photovoltaic project in Indonesia. The power plant is now in operation to inject power into the medium voltage distribution network of PLN in Kupang area.

\section{CURRENT STATUS}

Since their operation in 2013, PLTS Kayubihi and PLTS Karangasem have experienced setbacks which led to relatively low energy production. Research on the energy production and plant's performance index have been conducted by CORE members and the result has been submitted to journal and currently under review.

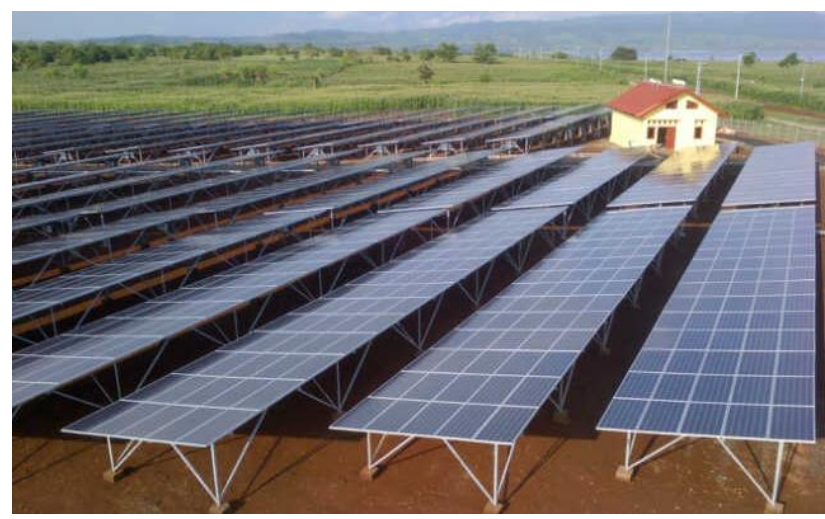

Fig. 6 PLTS 1 MW Labangka Sumbawa

In brief, the low energy production and performance ratio are associated with technical problems. Some components including the wirings or installation of the power plant require regular maintenance but this has not been conducted regularly. Due to this, reliability of equipments diminished consequently, energy production of power plant is significantly low.

District government faced constraints in allocating budget for maintaining the power plant as the plant were not yet registered under Perusda, the local government entity to manage the plant. It appears that many legal documents are required before central government could hand over project or assets to local government.Two institutions involved are Ministry of Finance and Office Secretary of State. After long process, Perusda PLTS Kayubihi and 
Government of Bangli, have been able to obtain formal documents with regards to the handover. In principle, based on this information, PLTS Kayubihi is now formally under the administration of Government of Bali or Perusda PLTS Kayubihi.

The case of PLTS Karangasem is slightly behind of what has achieved by PLTS Bangli. The stateenterprise established by Government of Karangasem was initiallykeen to respondthe program but due to lengthy process, and particularly uncertainty surrounding the administration of the hand over, and perhaps also due to head of district election, the activities of Perusda then slowed down and the latest communication by CORE to concluded the status of the plant is still unclear.

In the case of PLTS $5 \mathrm{MW}$ Kupang, since this project is fully funded by private investment, it looks that project preparation had been executed in a way to ensure smooth running of the project beyond construction and commissioning periods. For example, the power purchasing agreements (PPA) with the PLN had been signed before the project started. This is important to guarantee that when the plant is completed and power is produced, it then can be injected to the utility grid knowing that the energy will be purchased with a certain price and for certain period of time. The PPA between PLN and PT LEN has been signed and the tariff was set at 25 cent/kWh with contract supply for 20 years.

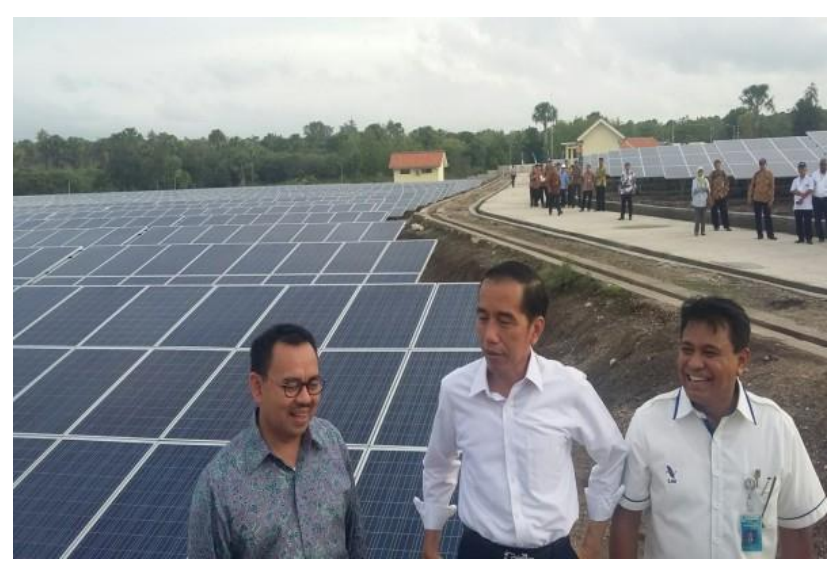

Fig. 7 Minister of MEMR (L), President Joko Widodo, CEO PT LEN (R) at PLTS 5 MW Kupang
In the case of governments funded photovoltaic projects, many of the projects have experienced setbacks. The issues that cause the problems can be grouped into three main subject areas: (1) administration of the projects with regards to hand over mechanism and procedures to local government ornominated socialenterprise or any nondeveloper power plants, and (2) terms and conditions of FIT for government funded projects, and (3) regulation or obligation of the utility, in this case PT PLN Distribusi, in setting up PPA with local government enterprise or any other non-developer power generator.

Administration of the project covers the understanding of the cross-ministerial regulations related with new and renewable energy development. The terms such as determination of asset's value for government projects, criteria for nomination of power plant or project location, and terms and conditions for project handover, including terms and conditions of institution that could receive such grants.

The FIT regulation \#17/2013 released by MEMR does not describe any detail as to whom the FIT is applicable to with regard to project developer. So, from the regulation point view, any organization meets the criteria for FIT will automatically eligible for FIT rates set by the regulation, i.e. from 25 cent/ kWh to 30 cent/kWh depending on the source of plant's components. Higher domestic plant's components entitle for higher FIT. The regulation does not differentiate the type of the plant developer, i.e. any institution will be receiving the FIT based on assessment of plant's components source.

Utility, PLN Distibusi where the power plant is located, by regulation \#17/2013, shall purchase any power injected by DG developer. Article 2 of regulation \#17/2013 mandates the utility to purchase all of the power generated by DG developer who has been nominated as the winner of bidding process. It is clear from this regulation that PLN has a compulsory obligation to buy the energy injected by the DG developer.

Seen from these three aspects, the 
administrationprocedures of handing over the PLTS Kayubihi plant to District of Bangli has been solved although it has taken over two yearssince the plant is energized. The administrative aspects of the asset handover has been completed. However, due to lack of detail information with regards to FIT, the agreement with the local utility is still under review. Under FIT regulation $\# 17 / 2013$, PLN is obliged to buy the energy injected by PLTS Kayubihi with the price determined by level of domestic components used by the plant. However, throughout the discussion between the utility and Perusda, it surfaced that the utility was reluctant to adopt full rate of FIT \#17/2013 with arguments that District Government did not invest on the project but rather was a grant from central government. While this discussion between Perusda PLTS Kayubihi and PLN continued, the PLTS Kayubihi also continue injecting power into PLN's grid. Our latest, communication with Perusda PLTS Kayubihi conclude that agreement between the PLN has been achieved but with negotiateUse the "Insert Citation" button to add citations to this document.

d rate. The enterprise was happy with the decision and they are now entering into administration finalization.

\section{RECOMMENDATIONS}

MEMR need to identify all of its own NRE related regulations and any external regulations, by other ministries or state agencies, and harmonizing all regulations to create certainty among NRE stakeholders, particularly NRE developer.

In view of huge task of Government to develop more PV plant to meet the 2025 target, on which the Government would still have to build more power plants, then clear guidelines should be issued to prepare future grant recipient in conducting negotiation with the utility to reach agreement of the FIT.

With regard to current government funded projects, MEMR should produce guidelines both for grant recipient and the utility so that agreement between the two parties over FTI rate can be achieved. Perusda that received the power plant as grant will also invest in the future to ensure the plant will continue working according the design and therefore should also receive fair FIT rate although they do not contribute on the initial investment. If this cannot be achieved that future power plants will likely to experience similar problems.

Guidelines on how FIT shall be given to non-power developer such as NGOs, social enterprise, CSR-based plants, international aid funded power plant, and the like should be issued so plant's operator (grant recipient) can prepare the required steps prior completion of the projects

\section{ACKNOWLEDGMENT}

This Policy Brief produced by Konsorsium "PETUAH" Perguruan Tinggi untuk Indonesia Hijau and funded by the Millenium Challenge Account (MCA) Indonesia

\section{REFERENCES}

Kepmen ESDM No 1122/2002 tentang Pembangkit Skala Kecil TERSEBAR, ESDM 2002

Kepmen ESDM No 17/2013 tentang Feed-in-Tariff untuk Pembangkit Listrik Tenaga Surya Fotovoltaik, 2013

\section{N. S. Kumara, W. G. Ariastina, I. W. Sukerayasa and} I. A. D. Giriantari, "On the potential and progress of renewable electricity generation in Bali," 2014 6th International Conference on Information Technology and Electrical Engineering (ICITEE), Yogyakarta, 2014, pp. 1-6. doi: 10.1109/ICITEED.2014.7007944

I. A. D. Giriantari, I. N. S. Kumara and D. A. Santiari, "Economic cost study of photovoltaic solar system for hotel in Nusa Lembongan," 2014 International Conference on Smart Green Technology in Electrical and Information Systems (ICSGTEIS), Kuta, 2014, pp. 13-16. doi: 10.1109/ICSGTEIS.2014.7038728

I. N. S. Kumara, W. G. Ariastina, I. W. Sukerayasa and I. A. D. Giriantari, "1 MWp grid connected PV systems in the village of Kayubihi Bali; Review on 
location's characteristics and its technical specifications," 2013 International Conference on Information Technology and Electrical Engineering (ICITEE), Yogyakarta, 2013, pp. 306311. doi: 10.1109/ICITEED.2013.6676258

IGN Adnyana, "Menuju Pasokan Kelistrikan Bali Yang Bersih: Current situation and future plan PT Indonesia Power dalammewujudkan Bali sebagai Pusat Energi Bersih" Focus Group Discussion on the Role of PT Indonesia Power toward Bale sebagai Kawasan Energi Bersih Nasional (KNEB), 10 June 2016, Denpasar

PA Budiana,"Pengembangan Centre of Excellence (COE) Energi Bersih di Provinsi Bali," Focus Group Discussion CORE, 7 March 2016, Denpasar

M Mendonca, "Success story FIT Support renewable energy in Germany," World Future Council

W Rickerson, "Feed-in Tariffs as a Policy Instrument for Promoting Renewable Energies and Green Economies in Developing Countries", UNEP, 2012 